\title{
SUSCEPTIBILITY OF TEN PEPPER BREEDING LINES TO CUCUMBER MOSAIC VIRUS DISEASE
}

\author{
${ }^{*}$ Adama, C. J., ${ }^{1}$ Salaudeen, M. T., ${ }^{1 B}$ Bello, L. Y., 2 Anyaoha, C. O. and ${ }^{3}$ Abdullahi, A. A. \\ 1Department of Crop Production, Federal University of Technology, Minna, Niger State, Nigeria \\ 2National Horticultural Research Institute, P.M.B. 5432, Jericho Reservation Area, Ibadan, \\ Nigeria \\ 3Department of Agricultural Technology, Niger State College of Agriculture, Mokwa, Nigeria \\ *Corresponding Author: cinwonj@gmail.com
}

\begin{abstract}
Pepper (Capsicum annuum) is a major vegetable of global importance. Its production is however affected by varying biotic and abiotic stresses. Virus infections possess a genuine danger to pepper cultivation in Nigeria and all over the world resulting in over $50 \%$ yield losses. Thus, the need to subject available pepper germplasm to screening against virus diseases for possible identification of resistant genes which may be used in breeding programmes to obtain improved lines that are high yielding. This study was undertaken to evaluate the growth and performances of ten pepper breeding lines under cucumber mosaic virus disease. The experiment was laid out in completely randomised design with five replications. Ten pepper breeding lines were evaluated as healthy and inoculated with cucumber mosaic virus and evaluated for their responses. Data were recorded for disease incidence, severity, growth and yield attributes. The data were subjected to analysis of variance. The results revealed that NHPK/D6-1-1 which showed mild disease incidence (36.7 \% on average) with an average severity (score $=2.2$ ), produced the highest number of leaves per plant (13) and branches (8) under diseased condition was the least vulnerable. The CMV-infected breeding lines were fruitless except for NHPK/D6-1-1 and NHPK/21-4-1-2 which produced an average of 2 fruits per plant. The selection of NHPK/D6-1-1 and NHPK/21-4-1-2 for further evaluation is therefore recommended for possible CMV-tolerant genes. The identification of virus-resistant breeding lines would provide more effective control of virus diseases in pepper production.
\end{abstract}

Keywords: Capsicum annuum; Cucumber mosaic virus; Breeding lines; NHPK 


\section{INTRODUCTION}

Pepper (Capsicum annum) is a major vegetable which is widely cultivated with several landraces (Bosland \& Votava, 2012). It can be served fresh or prepared chiefly as a flavor and sauce. It is used in stew and several local dishes all over Nigeria. Pepper is known for its pungency owing to the presence of an alkaloid known as capsaicin (8-methyl-N-vanillyl-6-nonenamide). Chili pepper generally contains about $1 \%$ capsaicin and it is rich in vitamins A, C and K (Perla et al., 2018). Nearly $90 \%$ of capsaicinoids in chili fruit is capsaicin and dihydrocapsaicin and these are pharmaceutically used for pain therapy, anti-obesity treatment, body temperature regulation, antioxidant, anticancer and antimicrobial therapy (Meghvansi et al., 2010). The world's pepper production in 2017 was about 36.1 million tonnes. Nigeria which produced 748, 559 tonnes was the largest producer in Africa (FAO, 2017). It is cultivated throughout the year, particularly in places with regular supply of water. Losses in pepper production have been reported from several bacteria, fungi and virus pathogens with viruses posing a more difficult threat in terms of management. In most fields, the incidence of virus diseases could be as high as $100 \%$ resulting in over $50 \%$ yield losses with attacks from strains such as Cucumber mosaic virus (CMV), Pepper veinal mottle virus (PVMV), Potato virus Y (PVY), Pepper mottle virus (PeMV) and Pepper mild mottle virus (PMMV) (Arogundade et al., 2015). Since most chemical pesticides are not effective for virus control, breeding for resistance remains the viable alternative for sustainable food production (Elvis et al., 2014). Despite the report that pepper has been cultivated for thousands of years (Perry and Flannery, 2007), there are limited improved pepper accessions that are resistant to virus diseases especially cucumber mosaic virus. Identification of resistance to CMV will facilitate the development and release of high yielding pepper varieties with appreciable tolerance to CMV in Nigeria. This study was therefore conducted to determine the susceptibility status of selected pepper breeding lines to CMV.

\section{MATERIALS AND METHODS}

\section{Plant Materials and Treatments Procedures}

The experiment was conducted at the Screenhouse of the Department of Crop Production,

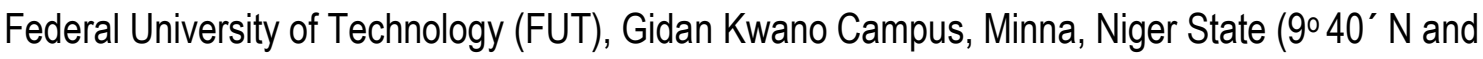
$6^{\circ} 30^{\prime} \mathrm{E}$ ) in the southern Guinea Savanna of Nigeria. Ten pepper breeding lines (NHPK/D4-4-1, NHPK/D6-1-1, NHPK/D6-1-4, NHPK/8-1-2-2, NHPK/21-4-1-2, NHPK/27-1-1-3, NHPK/31-1-3-2, NHPK/34-1-2-2-2, NHPK/59-2-1-2 and NHPK/60-5-4-2) sourced from the National Horticultural Research Institute (NIHORT) Ibadan were laid out in Completely Randomised Design (CRD) with five replications. The choice of the selected lines was based on lack of information on their characteristics and responses to CMV. The plant materials were developed by subjecting a base population of Nsukka yellow pepper cultivars sourced from farmers' field in Nsukka community of Enugu State to four cycles of phenotypic and recurrent selections with selfing. Uninoculated but 
buffer treated plants were maintained in a separate screenhouse as control (healthy). Plants were inoculated with an isolate of CMV.

\section{Sowing and Inoculation of Seedlings}

Pepper seeds were raised in plastic pots filled with heat sterilized loamy soil. The seeds were broadcast on 29th August, 2018 and were tendered for 21 days before they were transplanted into plastic pots measuring $30 \mathrm{~cm}$ and $25 \mathrm{~cm}$ deep filled with heat sterilized loamy soil. The seedlings were infected with CMV at 2 weeks after transplanting. Inoculum was prepared by grinding CMV-infected leaves with extraction buffer (Kumar, 2009). One microlitre of $\beta$-mercapto ethanol was added to the buffer just before inoculation in order to aid the breakdown of the plant cell wall. Inoculation was by rubbing the upper surface of the leaves with the sap after dusting with Carborundum powder (600 mesh). Excess inoculum was lightly washed off with distilled water. The plants were observed daily for symptoms expression.

\section{Data Collection and Analysis}

Disease incidence was recorded at 1 and 2 weeks post inoculation (WPI), as percentage of the total plants that developed symptoms of CMV disease. Severity was scored using a scale of 1-6 (Arogundade et al., 2015) as below:

$1=$ Asymptomatic leaves;

$2=$ About $25 \%$ of leaf surface exhibited symptoms of infection;

$3=$ Symptoms appeared on $50 \%$ of leaf surface;

$4=$ Up to $70 \%$ of leaf surface exhibited symptoms of CMV;

$5=$ Symptoms were present of $75 \%$ of the leaf surface; and

$6=$ Severe mosaic, $100 \%$ leaf yellowing and plant death.

Data were also collected on plant growth and yield parameters. The data collected were subjected to analysis of variance (ANOVA) at $p \leq 0.05$ using Statistical Analysis System (SAS, 2008).

\section{RESULTS}

\section{Disease Incidence and Severity in Pepper breeding lines inoculated with CMV}

The symptom expressed varied from mild mosaic to severe mosaic and leaf yellowing. All the CMV-inoculated plants elicited disease symptoms at 1 Week Post Inoculation (WPI) whereas the healthy plants showed normal growth. There were significant $(p<0.05)$ severity differences among the infected pepper lines (Table 1). At 1 WPI, CMV disease incidence ranged between 13. $3 \%$ (NHPKD4-4-1) to 86.7\% (NHPK/59-2-1-2). The difference in incidences of disease was not significant $(P>0.05)$ between NHPK/27-1-1-3 (66.7 \%) and NHPK/60-5-4-2 (60.0\%); NHPK/8-12-2 (53.3 \%) and NHPK/21-4-1-2 (53.3\%); NHPK/D6-1-1 (33.3\%), NHPK/D6-1-4 (46.7\%) and NHPK/34-1-2-2-2 (33.3\%). However, NHPK/31-1-3-2 differed significantly from others with CMV 
incidence of 20.0\%. Disease progression was recorded at 2 WPI, NHPK/27-1-1-3 and NHPK/592-1-2 showed the greatest disease incidence (93.3\%). This was closely followed by NHPK/21-41-2 (80.0\%) whose disease progress was statistically at par with NHPK/D6-1-4 (66.6\%), NHPK/81-2-2 (73.3\%) and NHPK/60-5-4-2 (73.3\%). The least disease incidence was elicited by NHPK/D4-4-1 (20.0\%).

The differences in severity of CMV disease on the evaluated lines were significant at 2, 4, 6 and 8 WPI (Table 1). Disease severity scores ranged from 1.6 (NHPK/D4-4-1) to 3.0 (NHPK/59-2-1-2) at 2 WPI. NHPK/D6-1-1(2.0), NHPK/D6-1-4(2.2), NHPK/8-1-2-2(2.4), NHPK/21-4-1-2(2.4), NHPK/27-1-1-3(2.6), NHPK/31-1-3-2(2.6), NHPK/34-1-2-2-2(2.0) and NHPK/60-5-4-2(2.4) showed statistically similar disease severity scores. At $4 \mathrm{WPI}$, most of the lines showed increased disease severity except for pepper line NHPK/D6-1-4 (score $=2.0$ ), NHPK/8-1-2-2 (score $=2.0$ ) and NHPK/31-1-3-2 (score $=2.4$ ) where a decline was recorded. NHPK/59-2-1-2 however still had the highest disease severity. At 6 and 8 WPI, disease severity significantly decreased $(p<0.05)$ across the evaluated lines except for NHPK/8-1-2-2 which maintained a severity score of 2.0 at 6 WPI. This however reduced at 8 WPI with a disease severity score of 1.0. Pepper line NHPK/59-2-1-2 showed the greatest severity score (3.0) at 6 WPI, this was statistically similar to NHPK/21-4-1-2, NHPK/27-1-1-3 and NHPK/60-5-4-2 with severity scores 2.6, 2.8 and 2.6 respectively. NHPK/D6-1-1, NHPK/8-1-2-2 and NHPK/34-1-2-2-2 showed severity score of 2.0. The lowest severity score of 1.0 were recorded against NHPK/D4-4-1, NHPK/D6-1-4 and NHPK/31-1-3-2. Furthermore, at 8 WPI, NHPK/59-2-1-2 had the greatest severity score (2.4). This was statistically similar to NHPK/21-4-1-2. Other lines recorded a CMV disease severity score ranging from 1.0 to 2.2 .

\section{Cucumber mosaic Virus Effect on Growth Performance}

Effect of treatments on number of leaves per plant: The healthy plants produced broad leaves with normal shapes as opposed to the CMV infected lines which produced numerous curdled smaller leaves. The number of leaves per plant differed significantly $(p<0.05)$ among all the healthy pepper lines. Number of leaves ranged from 3 (NHPK/21-4-1-2) to 9 (NHPK/34-1-2-2-2 and NHPK/59-2-1-2) per plant at 2 WPI (Fig. 1). NHPK/D6-1-1 and NHPK/60-5-4-2 had an average of 7 leaves per plant. Six leaves per plant were produced by NHPK/D4-4-1, NHPK/8-1-22, NHPK/31-1-3-2 which was similar to those produced by NHPK/D6-1-4 and NHPK/27-1-1-3 (5 leaves per plant). Considering the CMV infected lines, there were no significant $(p>0.05)$ differences across the lines. Number of leaves however ranged from 5 (NHPK/8-1-2-2) to 8 (NHPK/D4-4-1, NHPK/D6-1-1 and NHPK/21-4-1-2) per plant. At 4 WPI, uninoculated NHPK/34-12-2-2 produced the highest number of leaves (12 per plant). This was closely followed by NHPK/60-5-4-2 which produced an average of 10 leaves per plant. The least number of leaves per plant was observed in NHPK/8-1-2-2 and NHPK/21-1-1-3 which produced an average of 5 
leaves per plant. The CMV-infected lines recorded an increase in average number of leaves per plant at 4 WPI but this was statistically $(p>0.05)$ similar to those produced at 2 WPI. NHPK/D6-11 (11 leaves per plant) had the highest number of leaves and NHPK/60-5-4-2 produced the least (7 leaves per plant). Two weeks after (6 WPI), NHPK/34-1-2-2-2 produced the highest number of leaves (15 per plant) for the uninoculated pepper lines. NHPK/D6-1-1, NHPK/27-1-1-3, NHPK/311-3-2 and NHPK/60-5-4-2 were at par producing 10, 11, 12 and 13 leaves per plant respectively. NHPK/D4-4-1 and NHPK/D6-1-4 recorded nine leaves per plant with NHPK/8-1-2-2 and NHPK/21-4-1-2 producing eight leaves per plant. As opposed to what was obtained in the healthy plants, the infected lines produced 6 (NHPK/8-1-2-2) to 13 (NHPK/D6-1-1) leaves per plant. The number of leaves at 6 WPI was however not significant $(p>0.05)$ across the evaluated lines.

Effect of treatments on number of branches per plant: The numbers of branches per plant were significantly different $(p<0.05)$ across the uninfected pepper lines (Fig. 2). At 2 WPI, the number of branches ranged from 3 in NHPK/21-4-1-2 and NHPK/31-1-3-2 to 7 (NHPK/34-1-2-2-2 and NHPK/59-2-1-2) per plant. On the other hand, CMV infected lines were statistically similar with number of branches ranging from 3 (NHPK/8-1-2-2) to 5 (NHPK/D6-1-1, NHPK/31-1-3-2, NHPK/34-1-2-2-2, NHPK/59-2-1-2 and NHPK/60-5-4-2) per plant. At 4 WPI, the differences in number of branches per plant was however not significant $(p>0.05)$ but there was a change in this trend 14 days later. Infected pepper lines showed significant differences $(p<0.05)$ with NHPKD6-1-1 producing the highest number of branches (8 branches per plant). This was not significantly different from number of branches in NHPKD4-4-1 (6), NHPK/21-4-1-2 (7) and NHPK/34-1-2-2-2 (7). The least number of branches was recorded in NHPK/60-5-4-2 with 4 branches per plant. The number of branches at 6 WPI was not significantly different $(p>0.05)$ for the uninfected pepper lines, NHPK/60-5-4-2 and NHPK/34-1-2-2-2 produced 10 branches plant and 6 branches per plant was obtained as the least number of branches in NHPK/8-1-2-2, NHPK/21-4-1-2 and NHPK/59-2-1-2.

Effect of treatments on plant height: Cucumber mosaic virus (CMV) infection induced reduced plant height (Fig. 3). Uninfected pepper plants were generally taller than those infected with CMV. The data at 4 WPI revealed significant differences $(p<0.05)$ among the evaluated healthy uninoculated plants. Height differences varied from $8.3 \mathrm{~cm}$ (NHPK/8-1-2-2) to $14.0 \mathrm{~cm}$ (NHPK/605-4-2). NHPK/60-5-4-2 was closely followed by NHPK/59-2-1-2 with a height of $12.4 \mathrm{~cm}$. This was not significantly different from the heights of NHPK/27-1-1-3 $(11.5 \mathrm{~cm})$ and NHPK/34-1-2-2-2 $(11.5 \mathrm{~cm})$. For the heights of the infected plants, there were significant differences $(p<0.05)$ among the tested lines; NHPK/59-2-1-2 was the tallest $(11.1 \mathrm{~cm})$. The other lines were statistically at par with heights varying from $5.7 \mathrm{~cm}$ to $8.8 \mathrm{~cm}$. At 6 and $8 \mathrm{WPI}$, there were no significant differences $(p>0.05)$ among the tested pepper lines both for the healthy and the CMV infected treatments. NHPK/60-5-4-2 was still the tallest with a height of $19.4 \mathrm{~cm}$. Healthy NHPK/8-1-2-2 was the shortest at 8 WPI $(12.2 \mathrm{~cm})$. Considering the infected lines, NHPK/59-2-1- 
$2(11.9 \mathrm{~cm})$ was the tallest. The least height $(7.2 \mathrm{~cm})$ was recorded in NHPK/31-1-3-2 and NHPK/34-1-2-2-2.

Effect of treatments on yield parameters: The fruits of the healthy plants exhibited normal shape, in contrast to those infected with CMV which had uneven shape and ripening. Significant differences were not observed among the evaluated healthy breeding lines (Fig. 4). The healthy breeding lines produced between 1(NHPK/59-2-1-2) and 3 (NHPK/D6-1-1, NHPK/8-1-2-2, NHPK/21-4-1-2 and NHPKK/27-1-1-3) fruits per plant. In contracts to this, the CMV-infected breeding lines were fruitless expect for NHPK/D6-1-1 and NHPK/21-4-1-2 which produced an average of 2 fruits per plant.

\section{DISCUSSION}

Cucumber mosaic virus (CMV) is an aphid-borne major destructive virus affecting the global production of pepper. This has particularly reduced pepper production especially in the subSaharan region. All the lines showed varying forms of virus symptoms which was an indication of the susceptibility. This corroborates the findings of Olobashola et al. (2017), where two sweet pepper cultivars tested positive to CMV disease. One hundred percent disease incidence was not found on the inoculated lines, this indicated that there are some levels of resistance to the virus. This is against the findings of Suzuki et al. (2003) where eight Capsicum annum accessions were reported to be highly susceptible to CMV in a field trial. Disease severity was on the average in all the CMV inoculated lines, suggesting the presence of some level of tolerance to cucumber mosaic virus. This situation could be due to late infection as the plants were not inoculated till five weeks after sowing. As plants advance in age, they develop more effective mechanisms (structural and biochemical resources) for fight against pathogen attack. Cucumber mosaic virus infected lines were generally stunted; this was an indication of the negative effect of plant viruses on plant growth (Taiz \& Zeiger, 2010). When viruses colonize a host plant, they hijack the biochemical processes for their replication thereby reducing plants ability to produce sufficient food for proper growth and elongation supporting the findings of Kollmann et al., (2007). Furthermore, the number of fruits per plant produced by the healthy breeding lines was relatively higher than those observed in the CMV-infected lines where majority of the lines were fruitless. The inability of the most of the breeding lines to produce fruits was owing to the negative impact of plant viruses on crop performances. The ability of the lines to flower were grossly inhibited by the CMV infection rendering the lines unproductive supporting the findings of Damiri (2014) where some pepper cultivars were tested against CMV, TMV and Potato virus $Y$ (PVY).

\section{CONCLUSION}

All the pepper breeding lines were susceptible to CMV infection. However, NHPK/D6-1-1 which showed mild disease incidence, produced the highest 13 leaves per plant and 8 branches with an average of two fruits per plant under diseased condition was the most tolerant to CMV disease. 
The CMV-infected breeding lines were fruitless except for NHPK/D6-1-1 and NHPK/21-4-1-2 which produced an average of 2 fruits per plant. Selection of NHPK/D6-1-1 and NHPK/21-4-1-2 for further evaluation is recommended for possible CMV-tolerant genes. The identification of virus-resistant breeding lines would provide more effective control of virus diseases in pepper production.

Table 1: Disease Incidence and Severity in Pepper breeding lines inoculated with Cucumber mosaic virus

\begin{tabular}{|c|c|c|c|c|c|c|}
\hline \multirow[b]{3}{*}{ Pepper Line } & \multirow{2}{*}{\multicolumn{2}{|c|}{$\begin{array}{c}\text { Disease incidence (\%) } \\
\text { Week(s) after inoculation }\end{array}$}} & \multirow{2}{*}{\multicolumn{4}{|c|}{$\begin{array}{c}\text { Disease severity } \\
\text { Weeks after inoculation }\end{array}$}} \\
\hline & & & & & & \\
\hline & 1 & 2 & 2 & 4 & 6 & 8 \\
\hline NHPK/D4-4-1 & $13.3^{d}$ & $20.0^{c}$ & $1.6^{b}$ & $2.2^{\mathrm{cd}}$ & $1.0^{c}$ & $1.0^{b}$ \\
\hline NHPK/D6-1-1 & $33.3 b^{c d}$ & $40.0^{\mathrm{bc}}$ & $2.0^{a b}$ & $2.8^{\mathrm{bcd}}$ & $2.0^{\mathrm{b}}$ & $2.0^{a}$ \\
\hline NHPK/D6-1-4 & $46.7 \mathrm{bcd}$ & $66.6^{a b}$ & $2.2^{a b}$ & $2.0^{d}$ & $1.0^{c}$ & $1.0^{b}$ \\
\hline NHPK/8-1-2-2 & $53.3^{a b c}$ & $73.3^{a b}$ & $2.4^{a b}$ & $2.0 \mathrm{~d}$ & $2.0^{\mathrm{b}}$ & $1.0^{b}$ \\
\hline NHPK/21-4-1-2 & $53.3^{a b c}$ & $80.0^{a b}$ & $2.4^{a b}$ & $3.4^{a b}$ & $2.6^{a}$ & $2.4^{a}$ \\
\hline NHPK/27-1-1-3 & $66.7 \mathrm{ab}$ & $93.3^{a}$ & $2.6^{a b}$ & $3.2^{\mathrm{ab}}$ & $2.8^{a}$ & $2.2^{\mathrm{a}}$ \\
\hline NHPK/31-1-3-2 & $20.0^{c d}$ & $53.3^{a b c}$ & $2.6^{a b}$ & $2.4^{\mathrm{cd}}$ & $1.0^{c}$ & $1.0^{b}$ \\
\hline NHPK/34-1-2-2-2 & $33.3^{\mathrm{bcd}}$ & $53.3^{a b c}$ & $2.0^{a b}$ & $2.2^{\mathrm{cd}}$ & $2.0^{\mathrm{b}}$ & $1.8^{a}$ \\
\hline NHPK/59-2-1-2 & $86.7^{a}$ & $93.3^{a}$ & $3.0^{\mathrm{a}}$ & $3.8^{a}$ & $3.0^{\mathrm{a}}$ & $2.4^{a}$ \\
\hline NHPK/60-5-4-2 & $60.0^{\mathrm{ab}}$ & $73.3^{a b}$ & $2.4^{a b}$ & $3.0^{b c}$ & $2.6^{a}$ & $2.0^{\mathrm{a}}$ \\
\hline $\pm S E$ & 8.8 & 10.8 & 0.2 & 0.2 & 0.1 & 0.2 \\
\hline
\end{tabular}




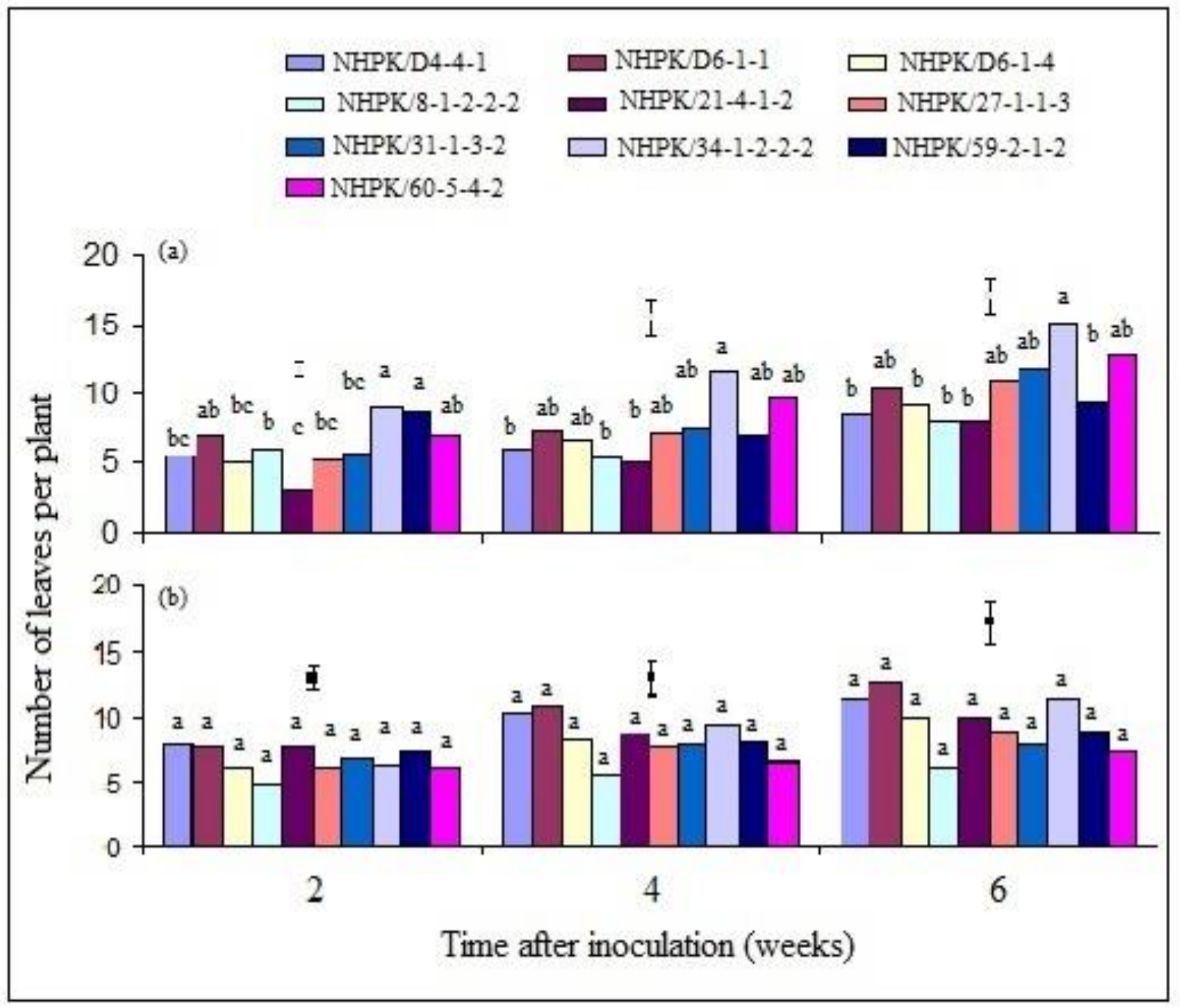

Fig. 1: Number of leaves per plant from healthy plants (a) and plants infected with Cucumber mosaic virus (b)

Bars with dissimilar letter(s) within column differ significantly $(p<0.05)$ by Student-Newman-Keuls (SNK) test

Note: Vertical bars are standard error of the means 


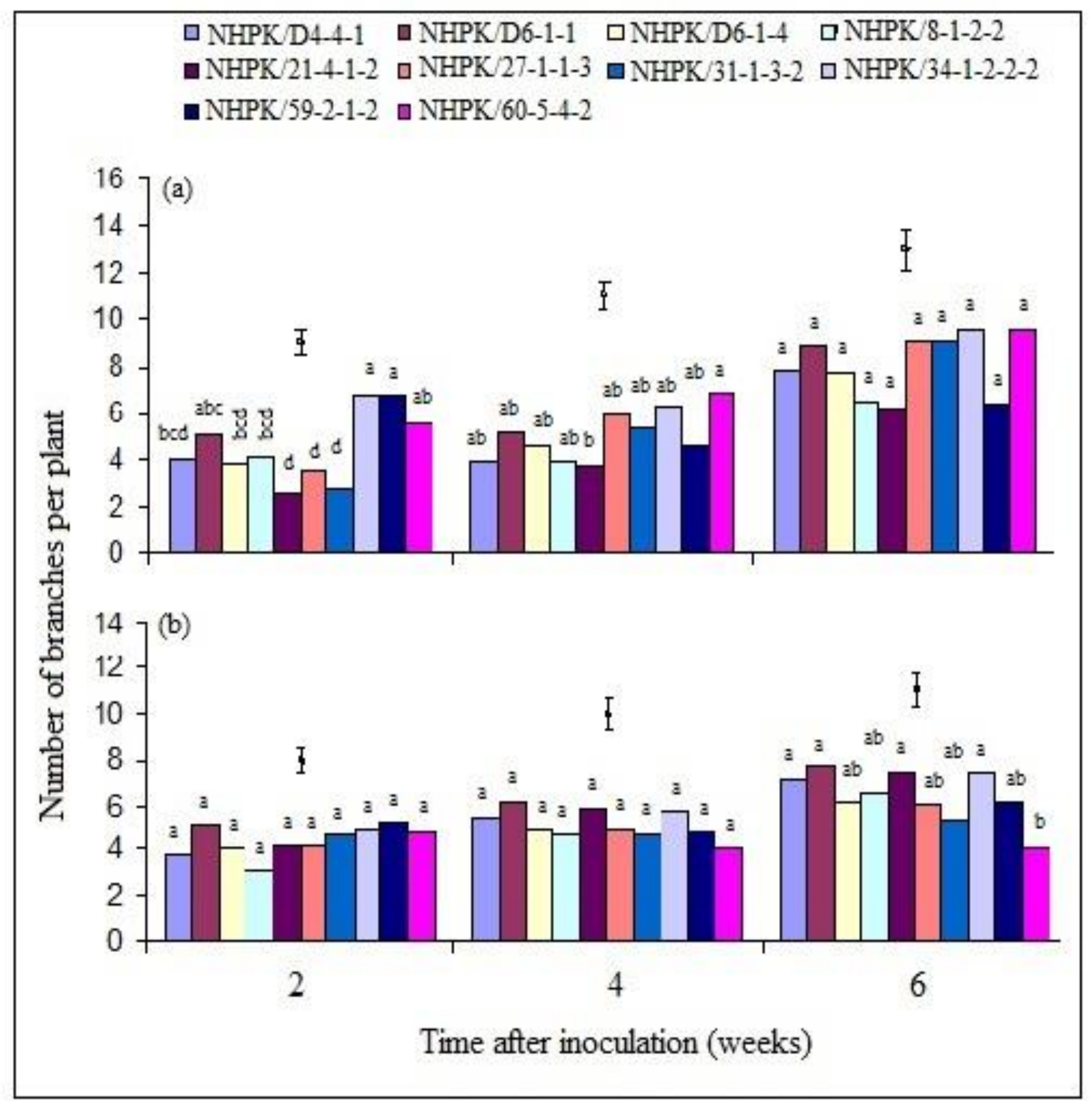

Fig. 2: Number of branches per plant from healthy plants (a) and plants infected with Cucumber mosaic virus (b)

Bars with dissimilar letter(s) within column differ significantly $(p<0.05)$ by Student-Newman-Keuls (SNK) test

Note: Vertical bars are standard error of the means 


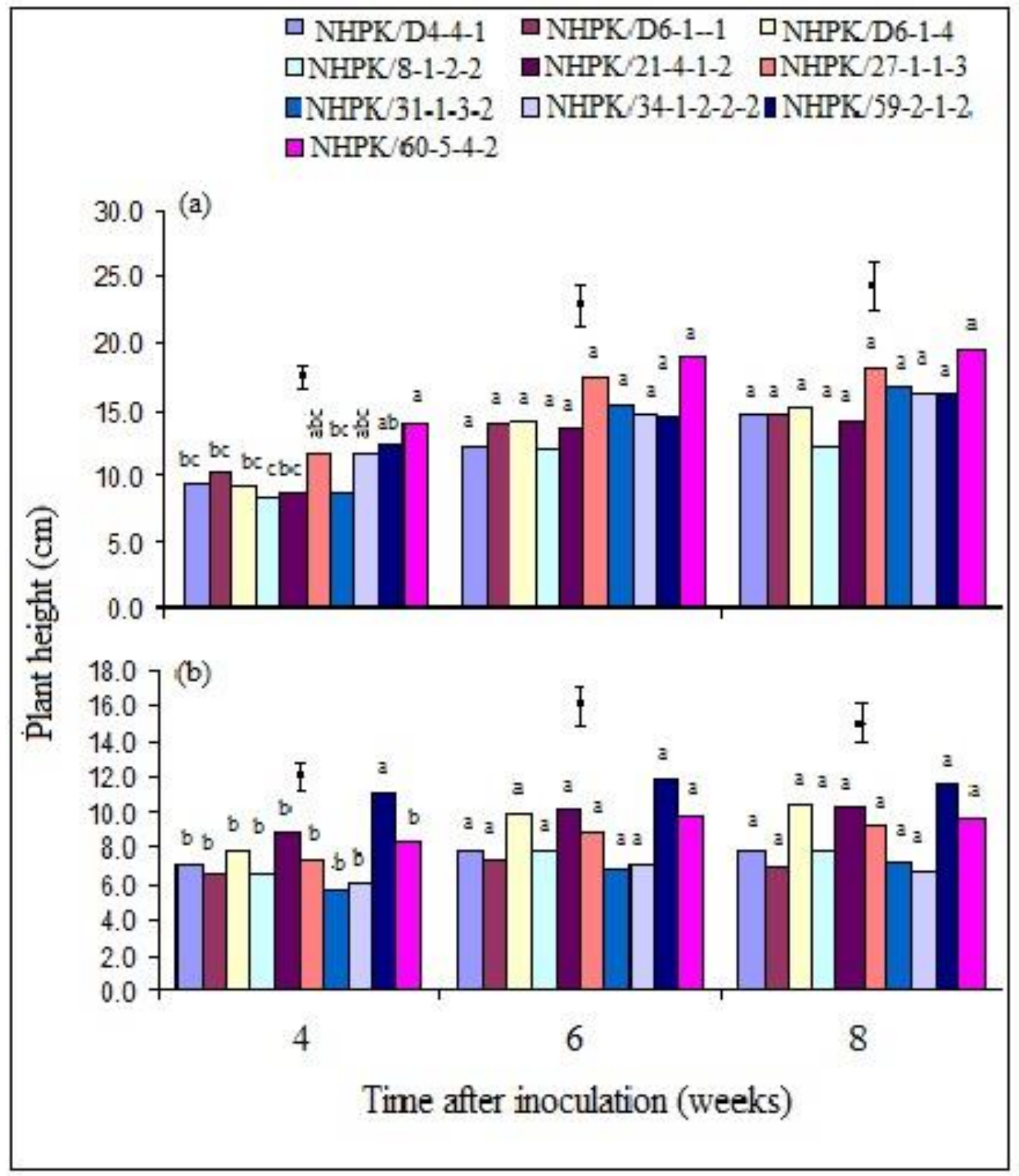

Fig. 3: Plant heights from healthy plants (a) and plants infected with Cucumber mosaic virus (b) Bars with dissimilar letter(s) within column differ significantly $(p<0.05)$ by Student-Newman-Keuls (SNK) test

Note: Vertical bars are standard error of the means 


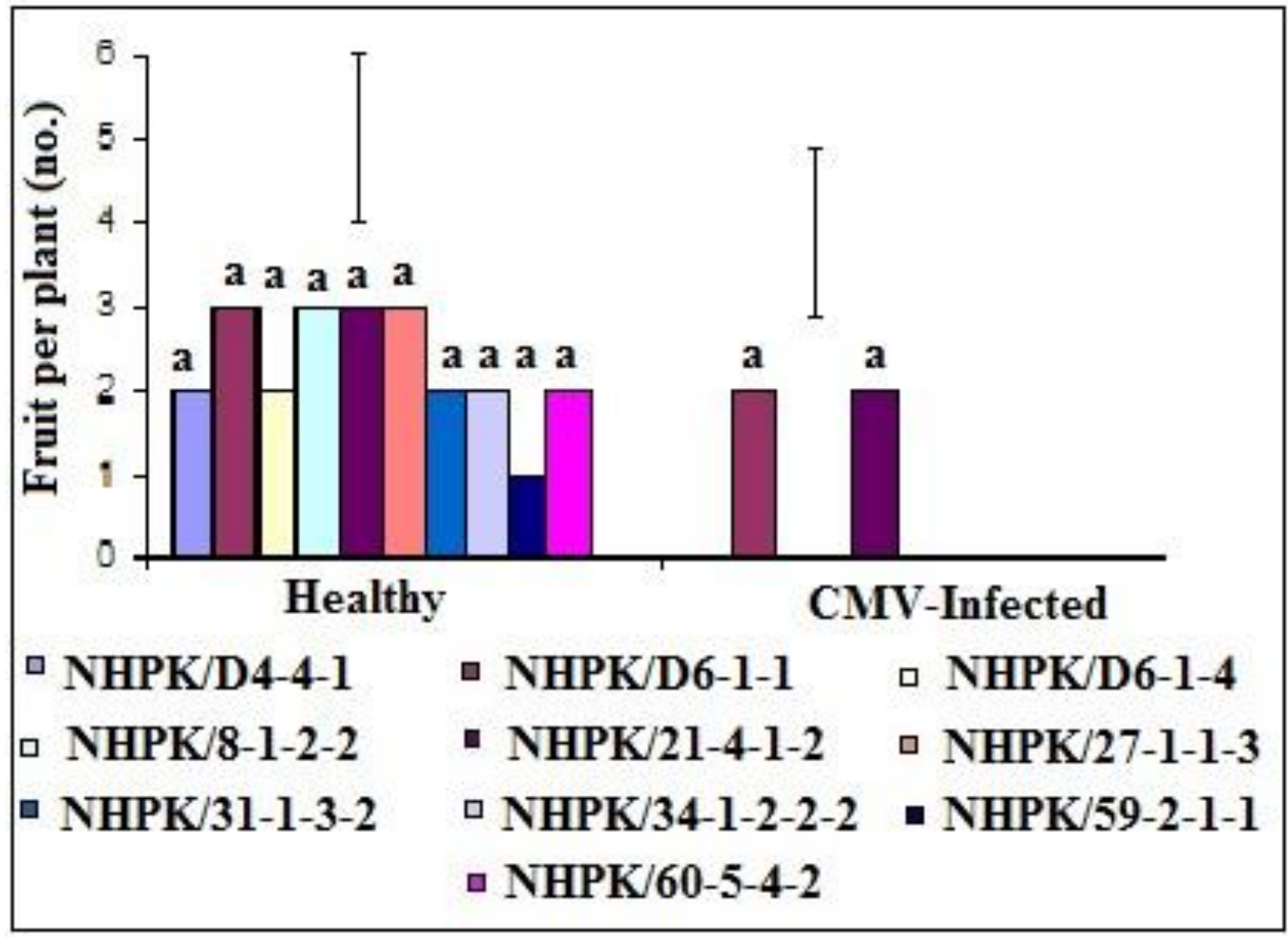

Fig. 4: Fruit per plant from healthy plants and plants infected with Cucumber mosaic virus Bars with dissimilar letter(s) within column differ significantly $(p<0.05)$ by Student-Newman-Keuls (SNK) test

Note: Vertical bars are standard error of the means 


\section{REFERENCES}

Arogundade, O., Balogun, O. S., Akinyemi, S. O. S. and Kumar, P. L. (2015). Surveys of virus diseases on pepper (Capsicum spp.) in South-west Nigeria. African Journal of Biotechnology, 14(48), 3198-3205.

Bosland, P. W. and Votava, E. J. (2012). Pepper: Vegetable and spice Capsicums, $2^{\text {nd }}$ edition, New York, NY: CABI Publishing.

Damiri, N. (2014). Mixed viral infection and growth stage on chilli (Capsicum annuum L.) production. Pertanika Journal of Tropical Agricultural Science, 37(2), 275-283.

Elvis, A., Albert, A. and Appiah, B. (2014). Comparative Efficacy of Phytopesticides in the management of Podagrica spp. And Mosaic Disease on Okra (Abelmoschus esculentus L.). American Journal of Experimental Agriculture, 4(8), 879-889.

FAO (Food and Agriculture Organization) (2017). Pepper production statistics. Available at http://faostat.fao.org/site/567/DesktopDefault.aspx?PagelD=567\#ancor. Accessed on July 1 , 2018.

Kollmann, J. I., Banuelos, M. J. and Nielsen, S. L. (2007). Effects of virus infection on growth of the invasive alien Impatiens glandulifera. Preslia, 79, 33-44.

Kumar, L. (2009). Methods for the diagnosis of Plants Virus diseases. Laboratory Manual, Ibadan IITA, 94pp.

Meghvansi, M., Siddiqui, S., Khan, M. H., Vairale, M. and Gogoi, H. (2010). Naga chili: a potential source of capsaicinoids with broad-spectrum ethnopharmacological applications. Journal of ethnopharmacology, 132(1), 1-14.

Olobashola, N., Salaudeen, M. T. and Achikwu, M. (2017). Growth and yield responses of sweet pepper (Capsicum annuum I.) cultivars to infections with Cucumber mosaic virus disease. Nigerian Journal of Agriculture, Food and Environment, 13(1), 201-205.

Perla, V., Nadimi, M., Reddy, R., Hankins, G. R., Nimmakayala, P., Harris, R. T., Valluri, J., Sirbu, C. and Reddy, U. K. (2018). Effect of ghost pepper on cell proliferation, apoptosis, senescence and global proteomic profile in human renal adenocarcinoma cells. PLoS ONE, 13(10), 1-27.

Perry, L. and Flannery, K. V. (2007). Precolumbian use of chili peppers in the valley of Oaxaca, Mexico. Proceedings of the National Academy of Sciences, 104, 11905-11909.

SAS (Statistical Analysis System) (2008). Statistical Analysis System SAS/STAT User's guide, ver. 9.2. SAS Institute Inc., Cary, N.C. 
Suzuki, K., Kuroda, T., Miura, Y. and Murai, J. (2003). Screening and field trials of virus resistant sources in Capsicum spp. Plant Disease, 87, 779-783.

Taiz, L. and Zeiger, E. (2010). Plant physiology. Sinauer Associates Inc, Sunderland, Massachusetts, USA. 